\title{
TAMAN BERMAIN ANJING PELIHARAAN
}

\author{
Samuel Rustandy ${ }^{1}$, Sidhi Wiguna Teh $^{21}$ \\ 1) Program Studi S1 Arsitektur, Fakultas Teknik, Universitas Tarumanagara, samzrush@gmail.com \\ 2) Program Studi S1 Arsitektur, Fakultas Teknik, Universitas Tarumanagara, sidhi@ft.untar.ac.id
}

\begin{abstract}
Abstrak
Kurangnya ruang yang ramah terhadap hewan peliharaan di Jakarta memunculkan gagasan untuk membuat tempat yang ramah hewan peliharaan. sebuah tempat yang dapat mewadahi pecinta hewanpeliharaan dan hewan peliharaannya untuk melakukan aktivitas selain di rumah. Sebuah tempat dimana manusia bisa berkumpul, berinteraksi, bersosialisasi antar manusia dan hewan peliharaannya. Sebuah tempat bermain dengan fasilitas fasilitas yang memadai untuk pemilik hewan peliharaan maupun hewan peliharaan itu sendiri. Kelapa Gading menjadi pilihan tempat dimana proyek ini akan dibangun karena Kelapa Gading mayoritas merupakan kawasan perumahan yang boleh diperkenankan memelihara hewan peliharaan. Kelapa Gading juga dihuni oleh orang golongan menengah ke atas yang diasumsikan mau mengeluarkan uang lebih untuk memanjakan hewan peliharaannya. Metode Perancangan berupa kajian pustaka, studi preseden, studi lapangan dan analisis terhadap program program yang memiliki kemiripan. Metode ini membantu memberikan informasi yang dibutuhkan dalam proses perancangan. Program utama dalam proyek ini adalah sebuah taman bermain anjing peliharaan dengan fasilitas pendukung seperti Toko Hewan, Salon Hewan, Klinik Hewan, Hotel Hewan, Kolam Renang Anjing, Restoran dan Kafe. Proyek ini diharapkan dapat memberikan manfaat dengan mengurangi tingkat stress penduduk metropolis yang butuh rekreasi sebagai penyegaran rohani dan jasmaninya dan meningkatkan sosialisasi antar penduduk yang dimana di kota metropolis penduduknya sangat individualis melalui hobi menyayangi hewan.
\end{abstract}

Kata kunci: Arsitektur Anjing, Bermain, Hewan, Sosialisasi, Rekreasi, Taman

\begin{abstract}
The lack of pet-friendly space in Jakarta raises the idea of making a place that is pet friendly, a place that can accommodate pet lovers and pets to do activities other than at home. A place where humans can gather, interact, socialize between humans and pets. A playground with adequate facilities for pet owners and pets themselves. Kelapa Gading is the choice of place where this project will be built because the majority of Kelapa Gading is a residential area that may be allowed to keep pets. Kelapa Gading is also inhabited by middle to upper class people who are assumed to be willing to spend more money to spoil their pets. Design methods in the form of literature studies, precedent studies, field studies and analysis of similar programs. This method helps provide information needed in the design process. The main program in this project is a pet dog playground with supporting facilities such as Pet Shop, Pet Salon, Pet Clinic, Pet Hotel, Dog Swimming Pool, Restaurant and Cafe. This project is expected to provide benefits by reducing the stress level of residents of metropolis who need recreation as a spiritual and physical refreshment and increase socialization among residents, where in the metropolis the population is very individualistic through the hobby of loving animals.
\end{abstract}

Keywords: Animals Architecture for Dogs, Park, Playing, Recreation, Socialization

\section{PENDAHULUAN Latar Belakang}

Provinsi DKI Jakarta merupakan kota metropolitan yang padat akan kegiatan manusia yang sehari hari bekerja. Kegiatan rutin bekerja setiap hari membuat manusia cenderung mengalami 
stres sehingga diperlukannya tempat untuk membuang penat dari rutinitas bekerja sehari hari. Banyak cara yang dapat dilakukan untuk menghilangkan kejenuhan terhadap aktivitas manusia dengan cara ber rekreasi. Tujuan dari rekreasi ini sendiri sebagai penyegaran jasmani dan rohani seseorang sehingga mengurangi kejenuhan nya akan aktivitas sehari harinya. Rekreasi setiap orang pun berbeda beda tergantung oleh beberapa faktor seperti ketersediaan waktu luang, jenis kelamin, usia, keluarga,dan faktor sosial ekonomi nya. Pada umumnya orang jalan jalan, olahraga, belanja, berkumpul, bermain serta melakukan hobinya untuk berekreasi. Di Jakarta sudah banyak tempat rekreasi seperti pusat perbelanjaan, perpustakaan, taman bermain, tempat olahraga, pusat kuliner, dll.

Bagi seorang pecinta hewan, bermain dengan binatang peliharaan nya di waktu senggang merupakan sebuah hobi kesenangan tersendiri yang dapat mengurangi tingkat stress pada dirinya. Jadi dapat disimpulkan bahwa dengan bermain bersama hewan peliharaan itu sebuah rekreasi yang menyegarkan rohani dan jasmani yang dapat menurunkan hormon stress, menurunkan tekanan darah, membuat lupa masalah, dan terapi untuk hati. Tetapi, di kota metropolitan ini kurang tempat yang ramah terhadap hewan peliharaan.

Banyak tempat seperti pusat perbelanjaan, kafe, restoran, taman yang tidak mengizinkan hewan hewan peliharaan ini untuk masuk. Kurangnya ruang yang ramah hewan ini memunculkan gagasan untuk membuat tempat yang ramah hewan peliharaan, sebuah ruang yang dapat mewadahi aktivitas bermain manusia dan hewan peliharaannya selain di rumah. Ruang ini juga harus dapat diakses oleh kalangan muda sampai kalangan tua sebagai wadah untuk menciptakan suatu komunitas yang dapat diakses oleh semua golongan, dimana orang orang bisa berkumpul, berdiskusi, dan bersosial.

\section{DISKUSI DAN HASIL}

Metode perancangan berawal dari pendekatan topik masalah yaitukurangnya tempat yang ramah terhadap hewan peliharaan di Jakarta sehingga memunculkan gagasan untuk membuat sebuah tempat bermain rekreasi yang ramah terhadap hewan peliharaan berupa taman bermain anjing peliharaan. Pemilihan lokasi proyek juga didasari analisis kecocokan dimana proyek akan dibangun secara makro melalui metode scoring site dengan poin penilaian berupa aksesibilitas, bentuk tapak, kondisi tapak, lingkungan sekitar, infrastruktur dan utilitas, kaitan strategis tapak, peruntukan tapak, kemudahan perluasan tapak, view dari tapak, dan nilai tambah tapak. Tapak pilihan dibandingkan dan dinilai keseluruhan untuk mendapatkan lokasi tapak yang tepat. Metode perancangan selanjutnya melalui metode pendekatan arsitektur dengan proyek proyek dengan kemiripan tujuan dan besaran yang sama.

Metode pendekatan ini berfungsi untuk mengumpulkan informasi informasi apa saja yang dibutuhkan di dalam proyek ini. Informasi seperti persentase besaran ruang, sistem pembuangan kotoran hewan, standar fasilitas hewan peliharaan, kebutuhan hewan peliharaan dari kebutuhan perawatan dan pengobatannya, material material yang aman dengan hewan peliharaan. Informasi didapatkan menggunakan metode survey untuk mengumpulkan data. Informasi informasi ini digunakan sebagai acuan dasar dalam pengembangan program kegiatan proyek taman bermain anjing peliharaan ini. Metode selanjutnya berupa analisis mikro lingkungan sekitar tapak. Data data analisis dikaji untuk melengkapi informasi informasi acuan dasar perancangan proyek. Dari semua metode tersebut telah diketahui Jakarta membutuhkan sebuah ruang yang dapat mewadahi aktivitas bermain manusia dan hewan peliharaannya dan menciptakan suatu komunitas yang dapat di akses oleh semua golongan, dimana orang orang bisa berkumpul, berdiskusi, dan bersosial.

Dari data dan informasi yang telah di kaji menghasilkan penzoningan pada tapak. Dalam konsep penzoningan terdapat tiga bagian penzoningan. Hal ini mendasari dari prinsip teritorial yang membatasi antara ruang publik dan ruang yang sifatnya privat. Penjelasan penzoningan tapak dijelaskan sebagai berikut. 
1. Zoning pertama yaitu untuk area publik, dimana area tersebut menjadi area yang sering dikunjungi dan menjadi area umum seperti lobby, ruang tunggu, pet shop, pet salon, pet clinic, dan restoran.

2. Zoning kedua yaitu untuk area semi publik, dimana area ini bisa di akses oleh pengunjung dengan persyaratan harus membayar tiket masuk. Zona ini merupakan zona fasilitas yang terdapat di proyek ini seperti dog swimming pool, dog park games, water play park, communal space garden.

3. Zoning ketiga yaitu untuk area privat. dimana area ini merupakan area penitipan anjing peliharaan. Tujuan membagi penzoningan area ini bertujuan untuk membuat ruang khusus tempat anjing beristirahat yang memerlukan privasi.

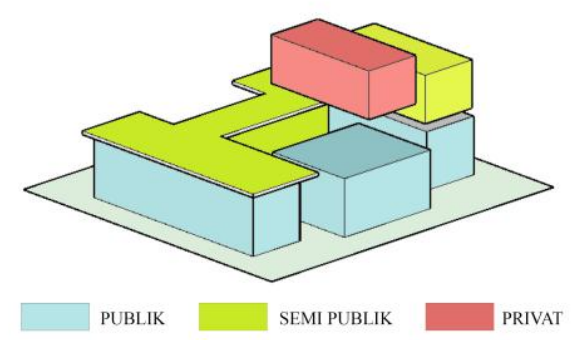

Gambar 1. Zoning Tapak

Sumber: pribadi

Konsep perancangan bangunan mengacu pada kompleksitas perancangan yaitu membuat ruang hijau (taman) yang luas dalam tapak yang hanya 2000 meter persegi. Konsep yang di terapkan pada bangunan ini merupakan konsep bangunan green continuity yang menerapkan prinsip menghadirkan lebih banyak ruang hijau di tanah yang kecil. Karena Ruang hijau dihadirkan lebih banyak, resapan air menjadi meningkat sehingga bangunan memberikan dampak positif untuk lingkungan.

Penerapan Green Continuity dilakukan dengan cara mengangkat taman hijau menjadi berada di area atap sehingga dibalik sebagai atap yang melindungi panas nya terik matahari, berguna juga untuk sebagai area hijau tambahan pengganti area yang terpakai untuk bangunan yang ada. Konsep Pembentukan gubahan massa berawal dari susunan zoning secara 3 dimensional. Berawal dari zona publik yang diletakkan di bagian lantai dasar tapak kemudian zona privat yang berada di lantai atas.

Struktur Bangunan terinspirasi dari teori 5 poin arsitektur modern Le Corbusier. Penerapan poin poin seperti pilotis, fasad bebas, desain seminimal mungkin menyentuh tanah, atap hijau, jendela horizontal di terapkan pada proyek ini. Teori 5 poin arsitektur modern Le Corbusier menjawab bagaimana konsep Green Continuity dapat terbangun. Peletakkan taman di atas untuk menambah ruang hijau dengan menggunakan struktur kolom sebagai penopang terinspirasi dari poin pilotis, roof garden, dan desain seminimal mungkin menyentuh tanah di teori 5 poin arsitektur modern Le Corbusier.

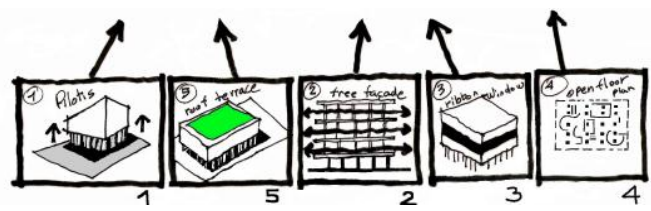

Gambar 2. Teori 5 Poin Arsitektur Modern Le Corbusier Sumber: Archidialog.com

Fasad yang terlepas dari dinding struktur juga membuat desain menjadi lebih menarik dan tidak kaku dengan bentuk bangunan. Fasad yang digunakan berupa kisi kisi kayu. Kisi-kisi pada umumnya banyak digunakan sebagai penghalang sinar matahari secara langsung. Selain itu, 
penggunaan kisi-kisi juga sering ditujukan untuk sirkulasi udara di dalam ruangan. Namun kini, kisi-kisi juga sering diaplikasikan sebagai elemen estetis. Motif garis-garis yang dihasilkannya menjadi aksentuasi pada ruanga. Dinding yang terlihat polos dengan warna solid atau jendela kaca yang membentang bisa tampak lebih atraktif berkat penempatan kisi-kisi di depannya.

Sedangkan untuk material indoor cenderung menggunakan material yang tahan terhadap air namun tetap natural. Material tahan air dipilih karena anjing cenderung bisa saja kencing di lantai, sehingga lantai harus bermaterialkan material yang tahan air seperti bebatuan, dinding semen ekspos, atau wood panel composite. Ketiga material ini terpadu sangat harmonis dengan fasad luar bangunan yang berupa kisi kisi kayu.

Untuk sistem pembuangan sampah, Pada tiap lantai, sistem pembuangan sampah yang terpisah jelas diterapkan untuk memisahkan sampah menjadi limbah anorganik dan limbah organik. Pada ruang-ruang terbuka yang berpotensi untuk area aktivitas bersama binatang peliharaan seperti taman, disediakan pet waste station untuk menampung kotoran hewan sehingga ruang terbuka tetap bersih dan sehat.

Kotoran binatang peliharaan dibuang dengan kantong kotoran binatang biodegradable, yang dapat dibeli di Toko Swalayan. BioBag dibuang di waste station maupun pet waste station, kemudian dikumpulkan oleh waste management staff. Kotoran yang telah dikumpulkan di daur ulang sebagai pupuk dengan menggunakan EnsoPet. EnsoPet berukuran diameter $40 \mathrm{~cm}$ dengan kedalaman $40 \mathrm{~cm}$. EnsoPet akan ditempatkan di taman terutama yang berdekatan dengan area pohon dan bunga.

\section{KESIMPULAN DAN SARAN}

Setelah melakukan kajian terhadap permasalahan yang ada di Jakarta dan penyelesaiannya dengan metode metode yang ada, terdapat beberapa kesimpulan yang disampaikan, di antaranya adalah konsep ruang yang dibutuhkan oleh pecinta hewan untuk bisa bermain bersama hewan peliharaannya, penyediaan fasilitas yang dibutuhkan untuk ruang ramah hewan peliharaan, memilih lokasi tapak yang sesuai dengan kebutuhan kawasan melalui analisa kawasan kawasan yang ada di Jakarta, menjawab rekreasi yang di tujukan kepada pecinta hewan peliharaan, dimana di Jakarta banyak tempat yang tidak ramah hewan peliharaan. Dengan adanya proyek ini diharapkan dapat memberikan manfaat dengan mengurangi tingkat stres penduduk metropolis yang butuh rekreasi sebagai penyegaran rohani dan jasmaninya dan meningkatkan sosialisasi antar penduduk yang dimana di kota metropolis penduduknya sangat individualis melalui hobi menyayangi hewan.

\section{REFERENSI}

5 Poin Arsitektur Modern Le Corbusier,diakses dari https://archidialog.com/tag/le-corbusirs fivepoints-of-architecture/, 1 Oktober 2018.

Sistem Utilitas Kotoran Hewan, diakses dari http://ejournal. uajy.ac.id10810/7/6TA14111.pdf, 5 November 2018. 


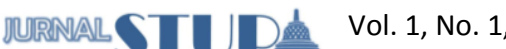

Sains, Teknologi, Urban, Perancangan, Arsitektur April 2019. hlm: 722-726 